\title{
TRAINING AUTODESK FUSION 360 FOR TEENAGE OF SENIOR HIGH SCHOOL GRADUATES IN IMPROVING ABILITY IN DISASTERS
}

\author{
Resa Trauna Suhada ${ }^{1}$, Silvi Ariyanti ${ }^{*}$, Anggun Vionieta Fajar ${ }^{1}$, Aam Komalasari! \\ ${ }^{1}$ Industrial Engineering Department, Universitas Mercu Buana \\ *ariyantisilvi41@gmail.com
}

\begin{abstract}
Autodesk launches Autodesk Fusion 360 - a cloud-based device that combines industrial design and 3D mechanics, collaboration, machinery in one package - the first solution available for purchase on Mac App Store worldwide including Indonesia. The Fusion 360 combines design, collaboration and machine tools into one package and is now available with the security and simplicity of the Mac App Store. With Fusion 360, designers and engineers can create products that have shapes and functions and prepare them for the fabrication process by using a single device. This community service activity is in the form of Autodesk Fusion 360 application training, with a total of 26 participants. Training activities include: introduction, visual demonstration and practice. The training materials are as follows: introduction of Autodesk Fusion 360, drawing 3-dimensional shapes, 3-dimensional drawing modifications, Solid modeling, Plotting. The purpose of this devotional activity is: Introduce and explain the basic theory of drawing using the computer, especially the use of Autodesk Fusion 360 program in the form of three dimensions. The benefits of this devotional activity are the junior high school graduates can recognize and apply computer-based drawing techniques. Improving the skills of high school graduates especially skills in the field of Fusion 360 applications. The results of this activity are the participants can carry out all product design activities and declared to pass and are entitled to receive a certificate issued directly by the company that produces Autodesk Fusion 360 Software.
\end{abstract}

Keywords: Fusion 360, 3D, solid

\section{INTRODUCTION}

Seeing the development of design in the rapidly expanding world of engineering, increasingly proves that the expertise in designing a product that can be used for various purposes will be one of the most promising skills, both in the world of work and in the field of education.

Information and communication technology is a technology that can help many kinds of work today, ranging from simple tasks to complex tasks that require various processes. It can not be denied that there is a significant increase if information and communication technologies are applied, compared to manual workmanship. The increase is certainly in accordance with the nature of technological advantages that brought about the increase in terms of process speed, accuracy of results, data storage, accuracy and precision size and can reduce human labor needs.

CAD (Computer Aided Design) is a computer program to draw a product. CAD can be shaped 2-dimensional or 3-dimensional images. The advantages of this CAD computer program to simplify and speed up in creating and changing a product image / component. Besides, this program also facilitate in complete image data such as material type, dimension, product number and so forth. The use of CAD software will help speed up the drawing process, more accurately and precision and the resulting image will be much nice, neat and clean. Design training is necessary to support the vehicle design process. With the design of the process of making product design can be done easily, but it is also known design analysis, product weight, airflow and so on.

Autodesk launched Autodesk Fusion 360 - a cloud-based device that combines industrial design and 3D mechanics, collaboration, machinery in one package - the first solution available for purchase on Mac App Store worldwide including Indonesia. Autodesk has done a remarkable job delivering a 
complete Fusion 360 device to the Mac App Store. The Fusion 360 combines design, collaboration and machine tools into one package and is now available with the security and simplicity of the Mac App Store. The basic method of design and manufacturing when experiencing radical changes. With Fusion 360 , designers and engineers can create products that have shapes and functions and prepare them for the fabrication process by using a single device. As a result, users can explore product ideas quickly and get prototype results much faster.

Fusion 360 also provides one room for all team members to collaborate on a project. Fusion 360 's built-in data and sharing management ensures all models, designs and information are automatically archived, diversified, managed and securely shared with other stakeholders. In addition, cloud-based solutions mean designers can access Fusion 360 anytime, anywhere. When used for free (Autodesk Software or cloud-free services that can be obtained for free can only be used for educational purposes and based on acceptance and compliance with the terms and conditions of the software license agreement or terms of service. From these statements, the Autodesk Fusion 360 application is expected to become one of the competencies for high school graduates in Jakarta and around to improve their ability in product innovation especially in the design field. Mastery of Autodesk fusion 360 application is needed by teenagers of high school graduates, especially teenagers graduated from SMK majoring in mechanical engineering. Teenage high school graduates have limited skills in the field of design. Design is a skill that can help teenagers to have competencies that can help them become more humane.

\section{METHOD}

As implicit in the formulation of the problem, based on the rapid development of information technology, the Community Service Team gathered 20 high school graduates who have an interest in the design field to be trained to be able to apply Autodesk Fusion 360 software in generating creative designs.

This community service activity is in the form of Autodesk Fusion 360 application training, with a total of 20 participants. Training activities consisting of introduction,visual demonstrations and practice. Training materials are introduction to Autodesk Fusion 360, drawing 3 dimensional shapes, modify 3-dimensional images, solid modeling and plotting.

\section{RESULT AND DISCUSSION}

The results of the design conducted by the trainees are as follows:

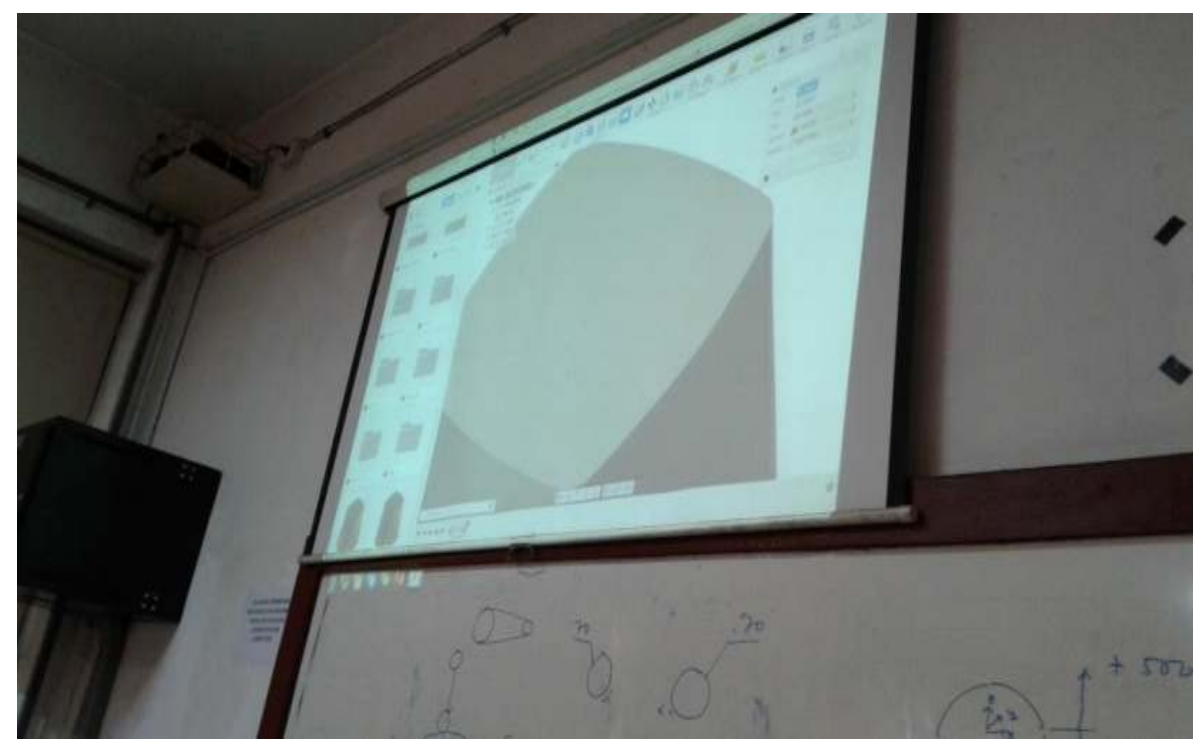

Figure 1. Initial Design of Workpiece of Plastic Chair 


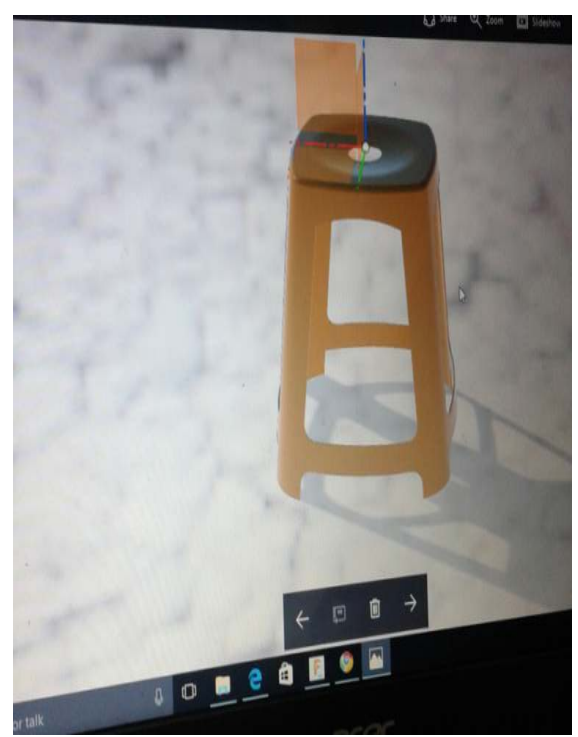

Figure 2. Plastic Chairs Design

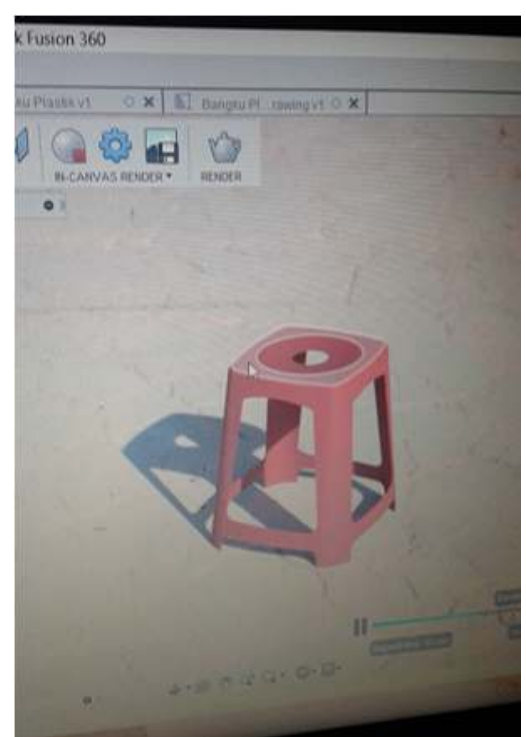

Figure 3. Design of Rechargeable Plastic Chairs

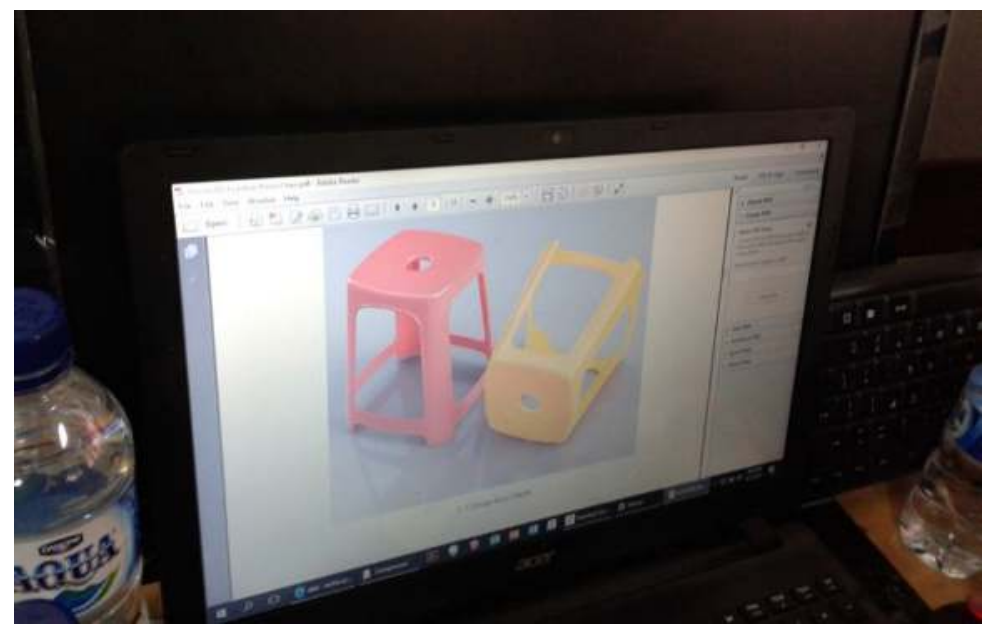

Figure 4. Design of Seat That Has So

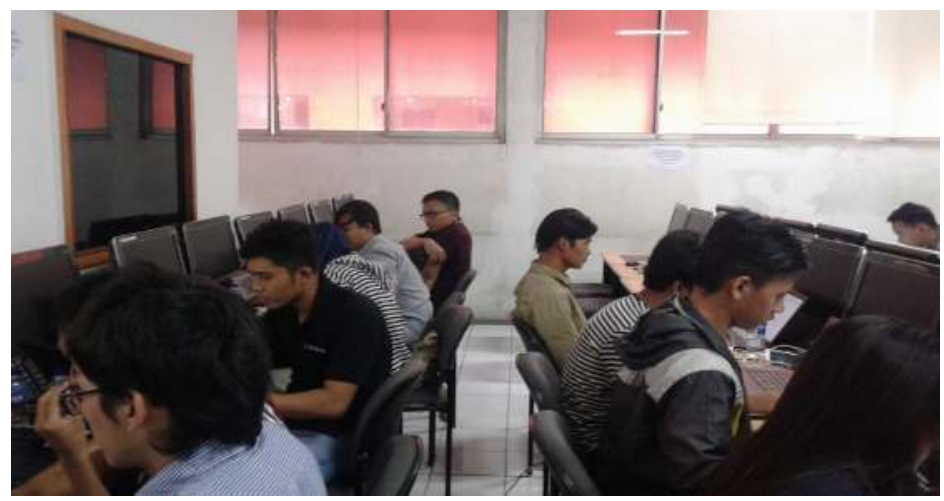

Figure 5. Training Participant Creating Design 
After participating in Autodesk Fusion 360 training participants can improve their ability to:

\section{Cognitive Aspects (Knowledge)}

Cognitive is the realm that emphasizes the change of one's knowledge. There are three stages emphasized in the training, which is about knowledge, understanding, and application. Training participants are able to understand the steps in operating Fusion 360 computer applications. The knowledge that trainees gain after the training can be applied through entrepreneurship in the field of graphic design, including mug design, banners and shirts.

\section{Affective Aspects (Attitude)}

Affective is the realm that emphasizes the changing attitudes and mindset of the trainees. There are three stages emphasized in this research, which is about the change of attitude that can be accepted by the trainee, the attitude in responding to the instructor and responding. The affective aspect of the trainees shows that the trainees experience a change of attitude, such as more confident in their ability, having good manners, being good during the course, able to help their fellow trainee if having difficulties in understanding the material, taking an active role when the discussion takes place, and the course activities that participated by the trainees provide many benefits for him/her.

\section{Psychomotor Aspects (Skills)}

Psychomotor is a field that emphasizes the skills of trainees. The psychomotor aspect of the trainees shows that the trainee understands about graphic design, operates the Fusion 360 application. The skills that are controlled by the trainees after attending Fusion 360 software training include design for mugs, t-shirts, banners and stickers.

\section{CONCLUSION}

The conclusion that can be taken in the implementation of community service activities is the activity carried out on 11 February 2017 at the University of Mercu Buana at the Computer Laboratory D208, at 8:00 to 17:00 WIB with the number of participants 26 people. And direct certificate by Autodesk International with instructor Didi Widya Utama ST. MT. The results of this activity participants can carry out all the product design activities and passed and are entitled to receive a certificate issued directly by the company that produces Autodesk Fusion 360 Software.

\section{REFERENCES}

Autodesk. (2014), 3Ds Max Interface Overview. Diakses dari: http://knowledge.autodesk.com/ support/3ds-max/learnexplore/caas/CloudHelp/cloudhelp/2015/ENU/3DSMax/files/GUID212A9477-E69E-4174-BB6F-1B7FD97A4281-htm.html. Pada tanggal 12 Mei 2015. Jam 21.00 WIB.

Autodesk. (2015). 3Ds Max Overview. Diakses dari http://www.autodesk.com/products/3dsmax/overview pada tanggal 9 Mei 2015. Jam 21.00 WIB

Brodklin, Jon. (2013). How Unity 3D Became a Game-Development Beast. Diakses dari : http://insights.dice.com/2013/06/03/how-unity3d-become-agame-development-beast/. Pada tanggal 14 Mei 2015. Jam 22.00 WIB.

The Three Aspects Of Software Quality: Functional, Structural, And Process. Diakses dari : http://www.davidchappell.com/writing/white_papers/The_Three_Aspects_of _Software_Quality_v1.0-Chappell.pdf pada tanggal 1 Juli 2015. Jam 21.30 WIB. 
Davis, Ziff. (2015). Definition of 3Ds Max. Diakses dari http://www.pcmag.com/encyclopedia/term/37087/3ds-max pada tanggal 910 Mei 2015. Jam 10.00 WIB.

Giraldi, Gilson. et al. (2005). Augmented Reality for Engineering Applications: Dinamic Fusion of DataSets and Real World. Universidade Estacio de Sa.

Suharso, Aries. (2012). Model Pembelajaran Interaktif Bangun Ruang 3D Berbasis Augmented Reality. Universitas Singaperbangsa Karawang. 